\title{
PENGARUH HARGA DAN KUALITAS PRODUK TERHADAP KEPUASAN PELANGGAN
}

\author{
Gita Vanya Meisara 1) \\ 1) Mahasiswa Program Studi Manajemen FE UNKRIS \\ Hotman Napitupulu 2) \\ 2) Dosen Program Studi Manajemen FE UNKRIS \\ Alamat: Kampus UNKRIS, Jatiwaringin Jakarta Timur \\ hotmannap15@gmail.com
}

\begin{abstract}
This research is intended to examine the effect of price and product quality on customer satisfaction both partially and simultaneously at PT Sophie Paris Indonesia, Pondok Gede branch. The research method used is descriptive and verification research methods. Data was collected using the questionnaire method, and data analysis used was multiple linear regression analysis.The results showed that price, product quality and customer satisfaction.
\end{abstract}

Keyword: Price, product quality, consumer satisfaction.

\section{PENDAHULUAN}

Daya ukur yang menjadi prioritas konsumen saat ini bukan hanya sekedar harga yang dapat dijangkau dengan kemampuan namun lebih dari mendapatkan kualitas produk untuk kurun waktu yang lama yang dianggap sesuai dengan besar harga yang dikeluarkan, dalam konsep pemasaran menyebutkan bahwa kunci untuk meraih tujuan perusahaan adalah menentukan kebutuhan dan keinginan pasar sasaran serta memberi kepuasan sasaran serta memberi kepuasan secara lebih efisien dan daripada yang diberikan pesaing (Kotler 2005).

Salah satu yang menjadi faktor dari kepuasan konsumen adalah harga, yang merupakan suatu nilai tukar yang bisa disamakan dengan uang atau barang lain untuk manfaat yang diperoleh dari suatu barang atau jasa. Dalam konteks secara luas yang menjadi penilaian penting adalah harga, harga dinilai menjadi acuan dasar utama dalam persaingan antar perusahaan, maka dari itu diperlukan pertimbangan secara rinci mengenai harga yang akan ditentukan dalam penjualan suatu produk karena mempengaruhi biaya pada produksi, tenaga kerja dan pemasaran serta biaya lainnya, sehingga diperlukan penentuan harga yang memiliki standar kualitas produk agar terciptanya kepuasan konsumen yang diharapkan oleh perusahaan. Harga yang ditawarkan PT Sophie Paris Indonesia berada di kalangan menengah yang mampu bersaing dengan berbagai merk pesaingnya dalam meningkatkan kepuasan konsumen serta memberikan kualitas produk dalam jangka panjang yang dapat memuaskan harapan konsumen.

Faktor lain yang mempengaruhi kepuasan konsumen dari suatu produk adalah kualitas produknya, dalam penilaian kualitas suatu produk sangat tergantung dari informasi yang melekat pada produk tersebut dan juga tergantung dari seberapa besar informasi 
tersebut dipahami oleh setiap individu. Informasi-informasi tersebut dapat berupa intrinsik dan ekstrinsik (Schiffman dan Kanuk: 2010). Kualitas produk di sini tidak hanya yang terlihat bagus di luar namun seberapa tahan atau handal suatu produk, sehingga kepuasan setelah mengkonsumsi atau menggunakan suatu produk tersebut yang akan membuat konsumen melakukan pembelian ulang di masa akan datang baik itu produk yang sama atau berbeda di perusahaan yang sama.

\section{LANDASAN TEORI}

\section{Harga}

Suatu perusahaan sebelum menetapkan harga harus memperhatikan metode-metode dalam menetapkan harga. Menurut Kotler dan keller (2016) yaitu : 1). Penetapan Harga Tingkat Pembelian Sasaran; Perusahaan menentukan harga yang akan menghasilkan tingkat pengembalian atas investasi sasarannya. 2). Penetapan Harga Nilai Anggapan; Nilai anggapan terdiri dari beberapa elemen seperti citra pembeli akan kinerja produk, kemampuan penghantaran dari saluran, kualitas jaminan, dukungan pelanggan, dan atribut yang kurang dominan seperti reputasi pemasok, kepercayaan dan harga diri. 3). Penetapan Harga Nilai; Metode yang menciptakan harga murah kepada pelanggan untuk menarik perhatian pelanggan dengan tidak mengabaikan kualitas produk perusahaan. 4). Penetapan Harga Goingrate; Perusahaan mendasarkan sebagian besar harganya pada harga pesaing, mengenakan harga yang sama, lebih mahal atau lebih murah dibandingkan harga pesaing utama. 5). Penetapan Harga Jenis Lelang; Penetapan harga jenis lelang dilakukan untuk membuang persediaan lebihatau barang bekas.

\section{Kualitas Produk}

Kualitas produk merupakan keseluruhan gabungan karakteristik produk yang dihasilkan dari pemasaran, rekayasa, produksi dan pemeliharaan yang membuat produk tersebut dapat digunakan memenuhi harapan pelanggan atau konsumen", yang didefinisikan menurut Wijaya (2011). Menurut Madura (2011) "kualitas produk adalah sejauh mana suatu produk yang diberikan perusahaan mampu memenuhi kebutuhan dan harapan konsumen". Sedangkan menurut Mowen (2012), "kualitas produk merupakan proses evaluasi secara keseluruhan kepada pelanggan atas perbaikan kinerja suatu produk". Menurut Fandy Tjiptono (2012) Kualitas produk merupakan suatu penilaian konsumen terhadap keunggulan atau keistimewaan suatu produk atau layanan secara menyeluruh.

\section{Kepuasan Konsumen}

Menurut Sangadji dan Sopiah (2013) menjelaskan bahwa "kepuasan atau ketidakpuasan adalah perasaan senang atau kecewa seseorang yang berasal dari perbandingan antara kesannya terhadap kinerja produk yang real atau aktual dengan kinerja produk yang diharapkan. Secara umum, kepuasan dapat diartikan sebagai adanya kesamaan antara kinerja produk dan pelayanan yang diterima dengan kinerja produk dan pelayanan yang diharapkan konsumen". Senada dengan pengertian menurut Adisaputro (2014) menjelaskan bahwa "kepuasan adalah perasaan seseorang untuk menjadi senang atau kecewa sebagai hasil dari perbandingan antara kinerja produk yang dipersepsikan (hasil atau outcome) yang dihubungkan dengan harapannya". 


\section{METODE PENEITIAN}

Metode yang akan digunakan dalam penelitian adalah kuesioner atau angket merupakan teknik pengumpulan data yang dilakukan dengan cara memberi seperangkat pertanyaan atau pernyataan tertulis kepada responden untuk dijawab menurut Sugiyono (2014).

Meotde analisis data yang digunakan afalah regresi linear, sebelum dilakukan analisis terlebih dahulu diuji instrumen data, yaitu uji validitas dan uji reliabilitas.

\section{HASIL PENELITIAN}

\section{Identitas Responden}

Membuktikan bahwa wanita terlihat sebagai konsumen yang lebih potensial dalam pembelian produk dibanding pria dengan jumlah 50 konsumen wanita, sementara pria hanya 10 konsumen.

Responden yang datang berbelanja langsung ke $\mathrm{BC}$ terlihat sudah sering mengunjungi dengan jumlah 3-5 kali kunjungan 12 konsumen, 6-10 kali kunjungan 30 konsumen dan >10 kali kunjungan sebanyak 18 konsumen.

\section{Uji Validitas Harga}

Dari hasil perhitungan koefisien korelasi skor butir pernyataan instrumen harga dari 60 responden dengan jumlah pernyataan masing-masing 6 butir. Dari 6 butir pernyataan dari variabel harga dapat dijelaskan bahwa nilai $\mathrm{R}$ hitung lebih besar dari > R kritis dengan nilai 0,30 hasilnya adalah 6 valid dan tidak ada yang invalid.

\section{Uji Validitas Kualitas Produk}

Dari hasil perhitungan koefisien korelasi skor butir pernyataan instrumen kualitas produk dari 60 responden dengan jumlah pernyataan masing- masing 8 butir. Dari 8 butir pernyataan dari variabel kualitas produk dapat dijelaskan bahwa nilai $\mathrm{R}$ hitung lebih besar dari > R kritis dengan nilai 0,30 hasilnya adalah 8 valid dan tidak ada yang invalid.

\section{Uji Validitas Kepuasan Pelanggan}

Dari hasil perhitungan koefisien korelasi skor butir pernyataan instrumen kepuasan konsumen dari 60 responden dengan jumlah pernyataan masingmasing 8 butir. Dari 8 butir pernyataan dari variabel kepuasan konsumen dapat dijelaskan bahwa nilai $\mathrm{R}$ hitung lebih besar dari > R kritis dengan nilai 0,30 hasilnya adalah 8 valid dan tidak ada yang invalid.

\section{Uji Reliabilitas}

Diketahui semua variable yaitu harga, kualitas produk dan kepuasan konsumen mempunyai koefisien alpha cukup besar di atas 0,60 yang berarti semua variabel dalam penelitian ini dapat diandalkan.

\section{Analisis Deskripsi}

Analisis deskripsi ini dimaksudkan untuk memberi gambaran dan penafsiran dari jawaban yang diberikan oleh para responden pada penelitian ini. Kuesioner disampaikan kepada responden dengan mengemukakan jawaban sesuai dengan pilihannya yang digolongkan dalam 5 kategori jawaban : (5) Sangat Setuju; (4) Setuju; (3) Kurang Setuju; (2) Tidak Setuju; (1) Sangat Tidak Setuju.

\section{Deskripsi Harga}

Dari 6 butir pernyataan yang menjadi pilihan dari jawaban 60 responden tersebut yang mana responden dalam memberikan jawaban atas pernyataan dengan memberikan nilai pernyataan sangat setuju atau 
setuju atau kurang setuju atau tidak setuju atau sangat tidak setuju

\section{Butir 1: Harga Produk Dapat Dijangkau Sesuai Pendapatan}

Dari hasil pernyataan butir 1 menunjukkan bahwa persentase terbesar adalah setuju dengan skor 42 responden atau $70.0 \%$ dan sangat setuju 16 responden atau $26.7 \%$, serta kurang setuju 2 responden atau $3.3 \%$. dari hasil proses olah data di dapat angka rata-rata skor untuk pernyataan diatas dengan nilai 4.23 , yang berarti hasil pernyataan ini mengarah kepada setuju.

\section{Butir 2: Berbagai Produk Menawarkan Varian Harga}

Dari hasil pernyataan butir 2 menunjukkan bahwa persentase terbesar adalah setuju dengan skor 39 responden atau $65.0 \%$, sangat setuju 19 responden atau $31.7 \%$, serta kurang setuju dan tidak setuju masing-masing 1 responden atau $1.7 \%$ dari hasil proses olah data di dapat angka rata-rata skor untuk pernyataan diatas dengan nilai 4.27, yang berarti hasil pernyataan ini mengarah kepada setuju.

\section{Butir 3: Harga Dengan Kualitas Yang Diberikan Sesuai Harapan}

Dari hasil pernyataan butir 3 menunjukkan bahwa persentase terbesar adalah setuju dengan skor 40 responden atau $66.7 \%$ dan sangat setuju 19 responden atau $31.7 \%$, serta kurang setuju 1 responden atau $1.7 \%$ dari hasil proses olah data di dapat angka rata-rata skor untuk pernyataan di atas dengan nilai 4.30, yang berarti hasil pernyataan ini mengarah kepada setuju.

\section{Butir 4 : Harga Produk Sesuai Dengan Produk Yang Ditawarkan}

Dari hasil pernyataan butir 4 menunjukkan bahwa persentase terbesar adalah setuju dengan skor 37 responden atau $61.7 \%$ dan sangat setuju 22 responden atau 36.7\%, serta kurang setuju 1 responden atau $1.7 \%$ dari hasil proses olah data di dapat angka rata-rata skor untuk pernyataan di atas dengan nilai 4.35 , yang berarti hasil pernyataan ini mengarah kepada setuju

\section{Butir 5 : Harga Produk Yang Ditawarkan Sesuai Dengan Manfaat Yang Dirasakan \\ Dari hasil pernyataan butir 5} menunjukkan bahwa presentase terbesar adalah setuju dengan skor 42 responden atau $70.0 \%$ dan sangat setuju 18 responden atau $30.0 \%$, dari hasil proses olah data di dapat angka rata-rata skor untuk pernyataan di atas dengan nilai 4.30, yang berarti hasil pernyataan ini mengarah kepada setuju.

\section{Butir 6 : Nilai Manfaat Yang Diperoleh Pelanggan Relatif Sesuai Dengan Harga Penawaran}

Dari hasil pernyataan butir 6 menunjukkan bahwa presentase terbesar adalah setuju dengan skor 40 responden atau $66.7 \%$ dan sangat setuju 18 responden atau $30.0 \%$, serta kurang setuju 1 responden atau $1.7 \%$ dari hasil proses olah data di dapat angka rata-rata skor untuk pernyataan di atas dengan nilai 4.25 , yang berarti hasil pernyataan ini mengarah kepada setuju.

\section{Deskripsi Kualitas Produk}

Jawaban yang menjadi pilihan responden sebanyak 60 responden melalui pernyataan pada kuesioner . selanjutnya akan dibahas atau analisa 8 butir pernyataan indikator kualitas produk yang menjadi pilihan responden tersebut dalam memberikan jawaban atas pernyataan dengan memberikan nilai pernyataan sangat setuju atau setuju atau kurang setuju atau tidak setuju atau sangat tidak setuju

Butir 1 : Kualitas Dan Harga Yang Sesuai Spesifikasi Saat Penawaran 
Dari hasil pernyataan butir 1 menunjukkan bahwa persentase terbesar adalah setuju dengan skor 43 responden atau $71.7 \%$ dan sangat setuju 12 responden atau $20.0 \%$, serta kurang setuju 5 responden atau $8.3 \%$ dari hasil proses olah data di dapat angka rata-rata skor untuk pernyataan di atas dengan nilai 4.12, yang berarti hasil permyataan ini mengarah kepada setuju.

\section{Butir 2 : Kualitas Produk Dengan Spesifikasi Produk Sesuai}

Dari hasil pernyataan butir 2 menunjukkan bahwa persentase terbesar adalah setuju dengan skor 39 responden atau $65.0 \%$ dan sangat setuju 17 responden atau $28.3 \%$, serta kurang setuju 4 responden atau $6.7 \%$, dari hasil proses olah data di dapat angka rata-rata skor untuk pernyataan di atas dengan nilai 4.22 , yang berarti hasil pernyataan ini mengarah kepada setuju.

\section{Butir 3 : Produk Memiliki Kualitas Bahan Tahan Lama Yang Baik}

Dari hasil pernyataan butir 3 menunjukkan bahwa persentase terbesar adalah setuju dengan skor 39 responden atau $65.0 \%$ dan sangat setuju 18 responden atau 30.0\%, serta kurang setuju 3 responden atau $5.0 \%$ dari hasil proses olah data di dapat angka rata-rata skor untuk pernyataan di atas dengan nilai 4.25 , yang berarti hasil pernyataan ini mengarah kepada setuju.

\section{Butir 4 : Produk Dapat Dipakai Dalam Jangka Waktu Panjang}

Dari hasil pernyataan butir 4 menunjukkan bahwa persentase terbesar adalah setuju dengan skor 37 responden atau $61.7 \%$ dan sangat setuju 20 responden atau $33.3 \%$, serta kurang setuju 3 responden atau $5.0 \%$ dari hasil proses olah data didapat angka rata-rata skor untuk pernyataan diatas dengan nilai 4.28, yang berarti hasil pernyataan ini mengarah kepada setuju.

\section{Butir 5 : Produk Memberikan Rasa Percaya Diri Dalam Pemakaian \\ Dari hasil pernyataan butir 5} menunjukkan bahwa persentase terbesar adalah setuju dengan skor 35 responden atau $58.3 \%$ dan sangat setuju 24 responden atau $40.0 \%$, serta kurang setuju 1 responden atau $1.7 \%$ dari hasil proses olah data didapat angka rata-rata skor untuk pernyataan diatas dengan nilai 4.38, yang berarti hasil pernyataan ini mengarah kepada setuju.

\section{Butir 6 : Pilihan Desain Berbagai Produk Dapat Diandalkan Karena Menarik}

Dari hasil pernyataan butir 6 menunjukkan bahwa persentase terbesar adalah setuju dengan skor 35 responden atau $58.3 \%$ dan sangat setuju 24 responden atau $40.0 \%$, serta kurang setuju 1 responden atau $1.7 \%$ dari hasil proses olah data didapat angka rata-rata skor untuk pernyataan diatas dengan nilai 4.38 , yang berarti hasil pernyataan ini mengarah kepada setuju.

Butir 7 : Kemampuan Pelayanan Yang Menyediakan Banyak BC Dan Layanan Online

Dari hasil pernyataan butir 7 menunjukkan bahwa persentase terbesar adalah setuju dengan skor 39 responden atau $65.0 \%$ dan sangat setuju 19 responden atau $31.7 \%$, serta kurang setuju 2 responden atau $3.3 \%$ dari hasil proses olah data di dapat angka rata-rata skor untuk pernyataan di atas dengan nilai 4.28 , yang berarti hasil pernyataan ini mengarah kepada setuju.

\section{Butir 8 : Kualitas Produk Dan Pelayanan Sesuai Dengan Kebutuhan}

Dari hasil pernyataan butir 8 menunjukkan bahwa persentase terbesar adalah setuju dengan skor 45 responden atau $75.0 \%$ dan sangat setuju 14 responden atau $23.3 \%$, serta kurang setuju 1 responden atau $1.7 \%$ dari hasil 
proses olah data di dapat angka rata-rata skor untuk pernyataan di atas dengan nilai 4.22 , yang berarti hasil pernyataan ini mengarah kepada setuju.

\section{Deskripsi Kepuasan Konsumen}

Dari 8 butir pernyataan yang harus di jawab oleh responden,

Butir1: Akan Mempertimbangkan Berbelanja Kembali diMasa Akan Datang

Dari hasil pernyataan butir 1 menunjukkan bahwa persentase terbesar adalah setuju dengan skor 35 responden atau $58.3 \%$ dan sangat setuju 24 responden atau $40.0 \%$, serta kurang setuju 1 responden atau $1.7 \%$ dari hasil proses olah data didapat angka rata-rata skor untuk pernyataan di atas dengan nilai 4.38, yang berarti hasil pernyataan ini mengarah kepada setuju.

\section{Butir 2 : Akan Tetap Membeli Produk Yang Sudah Memuaskan}

Dari hasil pernyataan butir 2 menunjukkan bahwa persentase terbesar adalah setuju dengan skor 36 responden atau $60.0 \%$, sangat setuju 15 responden atau $25.0 \%$, dan kurang setuju 8 responden atau $13.3 \%$, serta tidak setuju 1 responden atau $1.7 \%$ dari hasil proses olah data di dapat angka rata-rata skor untuk pernyataan di atas dengan nilai 4.08, yang berarti hasil pernyataan ini mengarah kepada setuju

\section{Butir 3 : Akan Mengatakan Hal Positif Tentang Pengalaman Menggunakan Produk Kepada Orang Lain \\ Dari hasil pernyataan butir 3} menunjukkan bahwa persentase terbesar adalah setuju dengan skor 38 responden atau $63.3 \%$ dan sangat setuju 18 responden atau $30.0 \%$, serta kurang setuju 4 responden atau $6.7 \%$ dari hasil proses olah data di dapat angka rata-rata skor untuk pernyataan di atas dengan nilai 4.23 , yang berarti hasil pernyataan ini mengarah kepada setuju.

Butir 4 : Akan Merekomendasikan Produk Kepada Teman dan Keluarga

Dari hasil pernyataan butir 4 menunjukkan bahwa persentase terbesar adalah setuju dengan skor 41 responden atau $68.3 \%$ dan sangat setuju 17 responden atau $28.3 \%$, serta kurang setuju 2 responden atau $3.3 \%$ dari hasil proses olah data di dapat angka rata-rata skor untuk pernyataan di atas dengan nilai 4.25 , yang berarti hasil pernyataan ini mengarah kepada setuju.

\section{Butir 5 : Akan Memperhatikan Citra Merek Yang Memberikan Kualitas dan Memuaskan \\ Dari hasil pernyataan butir 5} menunjukkan bahwa persentase terbesar adalah setuju dengan skor 42 responden atau $70.0 \%$ dan sangat setuju 17 responden atau $28.3 \%$, serta tidak setuju 1 responden atau $1.7 \%$ dari hasil proses olah data di dapat angka rata-rata skor untuk pernyataan di atas dengan nilai 4.25 , yang berarti hasil pernyataan ini mengarah kepada setuju.

Butir 6 : Saya Merasa Citra Merek Sophie Paris Memiliki Nilai dan Nama Yang Baik

Dari hasil pernyataan butir 6 menunjukkan bahwa persentase terbesar adalah setuju dengan skor 42 responden atau $70.0 \%$ dan sangat setuju 18 responden atau $30.0 \%$ dari hasil proses olah data di dapat angka rata-rata skor untuk pernyataan di atas dengan nilai 4.30, yang berarti hasil pernyataan ini mengarah kepada setuju.

Butir 7 : Akan Membeli Produk Lain Yang Ditawarkan Sophie Paris

Dari tabel hasil pernyataan butir 7 menunjukkan bahwa persentase terbesar adalah setuju dengan skor 44 responden atau $73.3 \%$ dan sangat setuju 16 
responden atau $26.7 \%$, dari hasil proses olah data di dapat angka rata-rata skor untuk pernyataan di atas dengan nilai 4.27 , yang berarti hasil pernyataan ini mengarah kepada setuju.

\section{Butir 8 : Saya Merasa Puas Dengan Mempertimbangkan Harga Dan Kualitas Produk Untuk Pembelian Selanjutnya}

Dari hasil pernyataan butir 8 menunjukkan bahwa persentase terbesar adalah setuju dengan skor 47 responden atau $78.3 \%$ dan sangat setuju 12 responden atau $20.0 \%$, serta kurang setuju 1 responden atau $1.7 \%$ dari hasil proses olah data didapat angka rata-rata skor untuk pernyataan diatas dengan nilai 4.18, yang berarti hasil permyataan ini mengarah kepada setuju.

\section{Hasil Penelitian Teknik Analisis Data dan Pembahasan}

\section{Uji Multikolinearitas}

Multikolinearitas adalah masalah yang timbul karena adanya hubungan linear antara variabel bebas yang ditunjukkan oleh adanya derajat kolinearitas yang tinggi. Model regresi yang baik harusnya tidak terjadi korelasi antara variabel bebas. Pedoman untuk mendeteksi suatu regresi yang bebas dari multikolinearitas adalah mempunyai nilai VIF disekitar angka 1 (satu) dan mempunyai nilai angka toleransi mendekati 1 (satu). Jadi nilai toleransi yang rendah $=$ nilai $\mathrm{VIF}$ yang tinggi (VIF = 1 atau toleransi ) dan menunjukan adanya kolinearitas yang tinggi. Seperti hasil pengujian multikolinearitas
Tabel 1. Koefisien Regresi

Coefficients $^{\mathrm{a}}$

\begin{tabular}{|c|c|c|c|c|c|c|c|}
\hline \multirow[b]{2}{*}{ Model } & $\begin{array}{r}\text { Unstai } \\
\text { Coeff }\end{array}$ & $\begin{array}{l}\text { adardiz } \\
\text { d } \\
\text { icients }\end{array}$ & $\begin{array}{c}\text { Standar } \\
\text { dized } \\
\text { Coeffic } \\
\text { ients }\end{array}$ & \multirow[b]{2}{*}{$\mathrm{T}$} & \multirow[b]{2}{*}{ Sig. } & \multicolumn{2}{|c|}{$\begin{array}{c}\text { Collinearity } \\
\text { Statistics }\end{array}$} \\
\hline & B & $\begin{array}{l}\text { Std. } \\
\text { Error }\end{array}$ & Beta & & & $\begin{array}{l}\text { Toler } \\
\text { ance }\end{array}$ & VIF \\
\hline $\begin{array}{l}1 \text { (Constan } \\
\text { t) }\end{array}$ & 3.840 & 2.931 & & 1.310 & .195 & & \\
\hline Harga & .459 & .149 & .345 & 3.087 & .003 & .491 & 2.038 \\
\hline $\begin{array}{l}\text { Kualitas } \\
\text { Produk }\end{array}$ & .537 & .114 & .524 & 4.692 & .000 & .491 & 2.038 \\
\hline
\end{tabular}

a. Dependent Variable: Kepuasan Konsumen

Berdasrkan pada tabel pengujian multikolinearitas di atas, dapat diketahui bahwa nilai tolerance variabel harga $=$ 0,491 , variabel kualitas produk $=0,491$ artinya nilai tolerance semua variabel lebih dari 0,1 dan nilai VIF dari variabel harga $=2,038, \quad$ VIF variabel kualitas produk $=2,038$ karena nilai VIF lebih kecil dari 10 maka dapat disimpulkan bahwa tidak terjadi gejala multikolinearitas diantara variabel bebas.

\section{Pengujian Hipotesis}

Nilai $\mathrm{R}=0.807$, artinya ada hubungan yang positif dan signifikan secara simultan harga dan kualitas produk dengan kepuasan pelanggan PT Sophie Paris Indonesia cabang Pondok Gede pada tingkat hubungan yang sangat kuat, sedangkan nilai R Square = 0.651, artinya kontribusi yang diberikan variabel harga dan kualitas produk secara simultan kepada variabel kepuasan konsumen PT Sophie Paris Indonesia cabang Pondok Gede adalah $65.1 \%$, sisanya $34.9 \%$ disumbangkan oleh variabel lain yang tidak diteliti oleh penelitian ini.

\section{Koefisien Regresi Berganda}

Nilai-nilai untuk persamaan regresi berganda sebagai berikut :

$$
\mathbf{Y}=\mathbf{a}+b_{1} X_{1}+b_{2} X_{2}+
$$




\section{$Y=3,840+0,459 X_{1}+0,537 X_{2}+$}

Dari persamaan tersebut dapat ditarik kesimpulan antara harga dan kualitas produk secara simultan memiliki hubungan yang positif dan searah.

Berdasarkan persamaan yang terbentuk di atas, nilai konstanta sebesar 3.840 memberikan makna pada saat $\mathrm{X}_{1}: \mathrm{X}_{2}=0$, maka $\mathrm{Y}$ sebesar 3.840 satuan. Dengan kata lain tanpa adanya harga, kualitas produk maka kepuasan pelanggan PT Sophie Paris Indonesia cabang Pondok Gede pada dasarnya telah terbentuk. Koefisien regresi berganda harga dan kualitas produk dapat diinterpretasikan bahwa dari koefisien regresi tersebut harga $\left(b_{1}\right)$, mendorong perubahan kepuasan konsumen sebesar 0.459 satuan, kualitas produk $\left(b_{2}\right)$ mendorong perubahan kepuasan konsumen sebesar 0.537 satuan. Kedua variabel tersebut berjalan searah dan positif, maka dapat disimpulkan variabel harga dan kualitas produk secara simultan (bersama-sama) memberikan sumbangsih yang positif atau memiliki hubungan dan pengaruh yang positif dan signifikan Pada kepuasan Pelangggan PT Sophie Paris Indonesia cabang Pondok Gede.

Nilai $F_{\text {hitung }}=53.216$ yang berarti pengujian simultan ini secara statistik menunjukkan bahwa variabel harga memiliki pengaruh positif dan signifikan terhadap kepuasan pelanggan PT Sophie Paris Indonesia cabang Pondok Gede.

.Nilai $\mathrm{r}=0.719$, artinya ada hubungan yang positif dan signifikan secara parsial harga dengan kepuasan konsumen PT Sophie Paris Indonesia cabang Pondok Gede pada tingkat hubungan yang kuat. Sedangkan nilai $\mathrm{R}$ Square $=0.517$, artinya bahwa kontribusi yang diberikan variabel harga secara parsial kepada variabel kepuasan pelanggan PT Sophie Paris Indonesia cabang Pondok Gede adalah 51.7\% sisanya $48.3 \%$ disumbangkan oleh variabel lain

Untuk persamaan regresi linear sederhana untuk variabel harga $\mathrm{Y}=$ $9.375+0.956 \mathrm{X}_{1}+$ e yang menunjukkan adanya koefisien garis regresi yang positif. Hal ini berarti garis regresi mempunyai lereng yang positif pula. Dengan demikian antara variabel harga dan kepuasan konsumen mempunyai hubungan yang positif dan searah.

Berdasarkan hasil pengujian empiris dan pengujian hipotesis yang tertuang dalam tabel di atas dapat diuraikan hal-hal yang berkaitan dengan hasil yang diperoleh, sebagai berikut: Nilai Koefisien Konstanta $=9.375$ memberikan makna bahwa persamaan tersebut secara matematis pada saat $\mathrm{X}_{1}$ $=0 ; \mathrm{Y}$ sebesar 9.375 yaitu pada saat dimana tidak ada upaya pemberian variabel harga terhadap kepuasan konsumen, kepuasan konsumen telah terbentuk.

Koefisien regresi variabel bebas harga 0.956 memberikan indikasi bahwa jika terjadi perubahan variabel bebas tersebut satu satuan, maka kepuasan konsumen akan berubah. Maknanya, harga memiliki hubungan dan pengaruh positif yang signifikan pada kepuasan pelangggan PT Sophie Paris Indonesia cabang Pondok Gede.

Berdasarkan pengujian hipotesis untuk variabel bebas harga yang menggunakan uji $t$, dimana $t$ hitung sebesar 7.872 dengan nilai signifikansi sebesar $0.000<0.05$, Hal tersebut memberikan makna bahwa Ho yang diajukan ditolak dan $\mathrm{Ha}$ di terima yang berarti pengujian ini secara statistik menunjukkan bahwa ada hubungan serta pengaruh positif dan signifikan antara variabel harga pada kepuasan pelanggan PT Sophie Paris Indonesia cabang Pondok Gede. 
Nilai $r=0.770$, artinya ada hubungan yang positif dan signifikan secara parsial kualitas produk dengan kepuasan konsumen PT Sophie Paris Indonesia cabang Pondok Gede pada tingkat hubungan yang kuat. Sedangkan nilai $\mathrm{R}$ Square $=0.593$, artinya bahwa kontribusi yang di berikan variabel kualitas produk secara parsial kepada variabel kepuasan konsumen PT Sophie Paris Indonesia cabang Pondok Gede adalah $\quad 59.3 \%$ sisanya $\quad 40.7 \%$ disumbangkan oleh variabel lain yang tidak di bahas pada penelitian ini.

Untuk persamaan regresi linear sederhana untuk variabel kualitas produk $\mathrm{Y}=7.025+0.789 \mathrm{X}_{2}+\mathrm{e}$ yang menunjukkan adanya koefisien garis regresi yang positif. Hal ini berarti garis regresi mempunyai lereng yang positif pula. Dengan demikian antara variabel kualitas produk dan kepuasan konsumen mempunyai hubungan yang positif dan searah.

\section{KESIMPULAN DAN SARAN}

\section{Kesimpulan}

Berdasarkan hasil pengujian empiris dan pengujian hipotesis yang tertuang dalam tabel diatas dapat diuraikan hal-hal yang berkaitan dengan hasil yang diperoleh, sebagai berikut : Nilai Koefisien Konstanta $=7.025$ memberikan makna bahwa persamaan tersebut secara matematis pada saat $\mathrm{X}_{2}$ $=0 ; \mathrm{Y}$ sebesar 7.025 yaitu pada saat dimana tidak ada upaya pemberian variabel kualitas produk terhadap kepuasan pelanggan, sebesar 7.025 satuan.

Koefisien regresi variabel bebas kualitas produk 0.789 memberikan indikasi bahwa jika terjadi perubahan variabel bebas tersebut satu satuan, maka kepuasan konsumen akan berubah sebesar 0.789 satuan.

Berdasarkan pengujian hipotesis untuk variabel bebas kualitas produk yang menggunakan uji $t$, dimana $t$ hitung sebesar 9.191 dengan nilai signifikansi sebesar $0.000<0.05$, Hal tersebut memberikan makna bahwa Ho yang diajukan ditolak dan Ha diterima yang berarti pengujian ini secara statistik menunjukkan bahwa ada hubungan serta pengaruh positif dan signifikan antara variabel kualitas produk pada kepuasan pelanggan PT Sophie Paris Indonesia cabang Pondok Gede.

\section{Saran}

1. Dengan harga produk yang terjangkau dengan diimbangi kualitas produk yang baik menjadi salah satu hal yang dapat menarik perhatian konsumen. Oleh karena itu hendaknya keunggulan yang diberikan PT Sophie Paris Indonesia dari segi mempertahankan harga yang terjangkau

2. Serta kaitannya kualitas produk dari perusahaan memegang peranan yang penting, dan tetap harus mempertahankan kualitas serta manfaat dari produk yang ada.

3. Kebijaksanaan dalam strategi mempertahankan PT Sophie Paris Indonesia di pasar, yang kaitannya dengan kepuasan pelanggan agar tetap dipertahankan dan ditingkatkan.

\section{DAFTAR PUSTAKA}

Abdullah, Thamrin \& Francis Tantri. 2016. Manajemen Pemasaran. Depok : PT Raja Grafindo Persada.

Adisaputro, Gunawan. 2014. Manajemen Pemasaran (Cetakan ke-2). Yogyakarta: Sekolah Tinggi Ilmu Manajemen YKPN

Agusty Ferdinand. 2014. Metode Penelitian Manajemen . UNDIP: Semarang.

Algifari. 2013. Statistika Induktif : untuk Ekonomi dan Bisnis. Yogyakarta: 
Sekolah Tinggi Ilmu Manajemen YKPN.

Alma, Buchari. 2014. Manajemen Pemasaran dan Pemasaran Jasa. Bandung : Alfabeta.

Ani Tristiana . 2016. Pengaruh Kualitas Produk Dan Harga Terhadap Kepuasan Konsumen Sepeda Motor Honda Vario 125. Jurnal Sekolah Tinggi IlmuEkonomi Indonesia. Jawa Timur

Arikunto, Suharsimi. 2014. Prosedur Penelitian Suatu Pendekatan Praktek. Jakarta : Rineka Cipta..

Arsyad, Soeratno. 1995. Metodologi Penelitian. Jogjakarta: UPP AMP YKPN.

Assauri, Sofjan. 2012. Manajemen Pemasaran. Jakarta : Rajawali, Gramedia Pustaka Utama

Effendi M. Guntur. 2010. Transformasi Manajemen Pemasaran. Jakarta : Sagung Seto.

Fandy Tjiptono, Ph.D dan Gregorius Chandra. 2012. Pemasaran Strategik. Yogyakarta : Andi Offset

Ghazali. 2016. Aplikasi Analisi Dengan Program Spss IBM Spss 23. Semarang : Badan Penerbit Universitas Diponegoro.

Hansen \& Mowen. 2012. Akuntansi Manajerial Buku 1 Edisi 8. Jakarta : Salemba Empat.

I.G.A Yulia Purnamasari. 2015. Pengaruh Kualitas Produk Dan Harga TerhadapKepuasan Konsumen Produk M2 Fashion Online Di Singaraja Tahun 2015. Jurnal Jurusan Pendidikan Ekonomi Universitas Pendidikan Ganesha. Singaraja.

Jessica J. Lenzun, James D.D. Massi,e Decky Adare. 2014. Pengaruh Kualitas Produk, Harga Dan Promosi Terhadap Kepuasan Pelanggan Kartu Prabayar Telkomsel. Fakultas Ekonomi Dan Bisnis Unsrat, Jurusan Manajemen
Universitas Sam Ratulangi Manado. Manado

Kotler, Philip \& Gary Armstrong. 2017. prinsip-prinsip pemasaran edisi 12 jilid2. Jakarta : Erlangga.

Kotler, Philip and Kevin Lane Keller. 2016. Marketing Management, (16thEdition), New Jersey: Prentice Hall Published.

Kotler, Philip. 2011. Manajemen Pemasaran di Indonesia : Analisis, Perencanaan, Implementasi dan Pengendalian. Jakarta : Penerbit Salemba Empat Kotler, Phillip dan Kevin L. Keller. 2015. Manajemen Pemasaran (Jilid 1, Edisi13). Jakarta : Erlangga.

Lupiyoadi, Rambat. 2013. Manajemen Pemasaran Jasa. Jakarta : Penerbit Salemba Empat.

Madura, Jeff. 2011. Pengantar Bisnis, Buku 1. Jakarta : Salemba Empat.

Novi Wahyu Worodiyanti dan Dr. Maspiyah, M.Kes. 2016. Pengaruh Kualitas Produk,Harga, Dan Kualitas Layanan Terhadap Kepuasan Konsumen Di Elladerma Skin Care Malang. Jurnal Fakultas Teknik, Universitas Negeri.Surabaya.

Sangadji, Dr Etta Mamang, M.Si \& Dr. Sopiah, M.M., Mpd. 2013. Perilaku Konsumen Pendekatan Praktis Disertasi Himpunan JurnalPenelitian. Yogyakarta : ANDI

Schiffman, Leon G. dan Leslie Lazar Kanuk. 2010. Consumer Behavior Tent Edition. Pearson Education.

Sugiyono. 2014. Metode Penelitian Kuantitatif, Kualitatif, dan $R \& D$.Bandung : Penerbit Alfabeta.

Umar, Husein. 2009. Riset Pemasaran dan Perilaku Konsumen. Jakarta : PT.Gramedia Pustaka Utama. 
Wijaya, Tony. 2011. Manajemen Kualitas Jasa. Edisi1. Jakarta : Indeks.

Zahra Ehsani dan Mohammad Hossein Ehsani. 2014. Effect of quality and price on customer satisfaction and commitment in Iran auto industry. Faculty of Management, Universiti Technologi Malaysia, Skudai, Johor Bahru, Johor, Malaysia and Faculty of Industrial Engineering, Khatam University, Tehran, Iran. 